\title{
PRAKTEK LANGSUNG PADA MATERI KOPERASI SEKOLAH DALAM UPAYA PEMBERIAN PENGALAMAN BELAJAR PADA SISWA SMAN 1 SEPUTIH RAMAN
}

\author{
M. REZA PAHLEVI \\ SMAN 1 Seputih Raman, Lampung Tengah \\ E-mail: pahlevi.inzagi@gmail.com
}

\begin{abstract}
ABSTRAK
Penelitian ini bertujuan menerapkan Metode Pembelajaran Eksperimental pada peserta didik dalam rangka memberikan pengalaman langsung dalam membentuk koperasi, menjalankan koperasi serta menghitung sisa hasil usaha. Jenis penelitian ini adalah Best Practice dengan subjek penelitian merupakan siswa kelas XII IPS 1 dan 2 sebanyak 59 siswa SMAN 1 Seputih Raman, Tahun Pelajaran 2017/2018 pada materi koperasi sekolah. Hasil Penerapan metode pembelajaran ini diperoleh nilai pengamatan sikap yang tinggi dalam indikator antusias, keaktifan, disiplin, kerjasama serta kreatifitas peserta didik. Hasil ujian tertulis juga diperoleh nilai rata-rata peserta didik yang tinggi serta tercapainya ketuntasan klasikal $(>80 \%)$.
\end{abstract}

Kata Kunci: Metode Pembelajaran Eksperimental, Pengalaman Belajar, Koperasi Sekolah.

\section{PENDAHULUAN}

Proses pembelajaran dikatakan berhasil apabila telah terjadi perubahan perilaku pada peserta didik. Perilaku ini tentunya terjadi akibat pengalaman yang terjadi selama proses pembelajaran berlangsung. Faktor yang berpengaruh disini adalah pengalaman kongkret, pengalaman aktif dan replektif, konseptualisasi dan eksperimentasi seorang pelajar (Daryanto,2009). Terkait pengalaman belajar kita tentunya tidak asing dengan kerucut pengalaman Edgar Dale yaitu pengalaman yang diperoleh dalam menggunakan media dari paling konkret (di bagian paling bawah) hingga paling abstrak (di bagian paling atas), (Dawson dan Kovalchick.ed,.2004).

Pengalaman belajar peserta didik sangat berperan dalam menumbuhkan kecakapan hidup yang dibutuhkan oleh peserta didik dalam kehidupan sesungguhnya. Ada dua bentuk kecakapan hidup yaitu kecakapan hidup generik dan kecakapan hidup spesifik. Kecakapan hidup generik adalah kecakapan hidup yang berkaitan dengan kecakapan berfikir dan memahami diri, sedangkan kecakapan hidup spesifik yaitu kecakapan untuk menghadapi pekerjaan atau keadaan tetentu. (Brolin,D.E. 1989). Peserta didik tidak hanya dituntut belajar menguasai dari sisi kognitif (pengetahuan), tetapi juga memiliki kemampuan psikomotorik ( keterampilan) yang dapat di aplikasikan dalam kehidupan sehari-hari , baik untuk kehidupan pribadi dalam rangka kemandirian hidup, lingkungan keluarga maupun dalam kehidupan bermasyarakat.

Salah satu materi ekonomi pada tingkat Sekolah Menengah Atas adalah materi Koperasi Sekolah. Materi ini seringkali diterima peserta didik hanya sebatas teori dan minim pengalaman langsung. Padahal Materi Koperasi Sekolah seharusnya memberi pengalaman langsung bagi peserta didik tentang bagaimana membentuk koperasi, menjalankan koperasi dan menghitung Sisa Hasil Usaha. Apabila peserta didik telah merasakan bagaimana mengelola koperasi sekolah maka diharapkan dengan pengalaman tersebut peserta didik tidak hanya memahami secara teori saja tetapi juga dapat menjalankan koperasi secara praktek. Tujuan jangka panjang lain yaitu peserta didik dapat mengelola koperasi bila kelak mereka terjun di masyarakat. Selama ini metode yang digunakan cenderung pada metode ceramah atau metode lain yang tidak memberikan pengalaman langsung bagaimana mengelola koperasi sekolah tersebut. Tentunya ini menjadi sebuah fenomena yang menjadi masalah terkait pengalaman peserta didik tentang bagaimana praktek koperasi sekolah itu sesungguhnya. Peran pendidik dalam memilih metode pembelajaran yang tepat diharapkan dapat memaksimalkan hasil belajar serta menghadirkan proses pembelajaran yang lebih bermakna dalam kehidupan peserta didik. 
Metode adalah cara, yang dalam fungsinya merupakan alat untuk mencapai tujuan, makin tepat metodenya, diharapkan semakin efektif pula pencapaian tujuan tersebut (Suryosubroto.2002). Salah satu metode pembelajaran yang menekankkan pengalaman langsung adalah Metode Eksperimental. Metode Pembelajaran Eksperimental merupakan cara menyajikan pelajaran, dimana siswa melakukan percobaan dengan mengalami sendiri sesuatu yang dipelajari (Djamarah, 2002). Menurut Roymond (2009) Metode pembelajaran eksperimental adalah suatu cara pengelolaan pembelajaran di mana siswa melakukan aktivitas percobaan dengan mengalami dan membuktikan sendiri suatu yang dipelajarinya. Dalam metode ini peserta didik diberi kesempatan untuk mengalami sendiri atau melakukan sendiri dengan mengikuti suatu proses, mengamati suatu obyek, menganalisis, membuktikan dan menarik kesimpulan sendiri tentang obyek yang dipelajarinya. Diharapkan dengan penerapan metode pembelajaran eksperimental dapat teratasinya permasalahan selama ini yaitu minimnya pengalaman peserta didik tentang pengelolaan koperasi, yang berdampak pada kurangnya pemahaman terhadap materi. Akibat kurangnya pemahaman terhadap materi terlihat dari nilai rata-rata peserta didik yang rendah dan ketuntasan klasikal yang tidak tercapai.

Berdasarkan latar belakang tersebut, penulis termotivasi untuk memberikan Materi Koperasi Sekolah dengan menggunakan metode pembelajaran yang lebih menekankan pada pengalaman langsung. Metode eksperimental ini penulis nilai cocok digunakan agar peserta didik untuk mendapatkan pengalaman langsung dalam membentuk koperasi, menjalankan koperasi serta menghitung Sisa Hasil Usaha. Diharapakan dengan menjalankan kegiatan koperasi secara langsung peserta didik bisa memahami materi dengan tidak terkungkung dalam kelas serta lebih menyenangkan. Lalu dalam pelaksanaan pembelajaran peserta didik dapat berinovasi secara mandiri sesuai dengan kreatifitas masing-masing. Dalam prakteknya peserta didik harus tetap memperhatikan rambu-rambu yang ditetapkan guru mata pelajaran terkait apa yang dapat dilakukan serta apa yang dilarang untuk dilakukan.

\section{METODE PELAKSANAAN}

Peneltian ini merupakan Best Practice yaitu sebuah karya tulis yang menceritakan pengalaman terbaik dalam menyelesaikan sebuah permasalahan yang dihadapi oleh guru, kepala sekolah, pengawas sekolah, dan tenaga kependidikan sehingga mereka mampu memperbaiki mutu layanan pendidikan dan pembelajaran di sekolah (Apandi, 2018). Metode pembelajaran yang digunakan dalam best practice ini adalah Metode Eksperimental. Waktu penulisan Best Practice ini adalah pada Semester Genap TP. 2017/ 2018 pada kompetensi dasar koperasi sekolah. Adapun sasaranya adalah kelas 12 IPS 1 dan 12 IPS 2 dengan jumlah total sebanyak 59 siswa. Penggunakan metode ekpserimental ini untuk memberikan pengalaman belajar peserta didik.

Adapun tahapan kegiatannya adalah dimulai dari menjelaskan tujuan pembelajaran, membagi peserta didik menjadi beberapa kelompok untuk membentuk sebuah koperasi, dilanjutkan dengan memberikan petunjuk teknis bagaimana kegiatan dilakukan. Termasuk didalamnya apa yang boleh dan yang tidak boleh dilakukan peserta didik dalam praktek koperasi sekolah tersbut.

Tahap selanjutnya adalah praktek kegiatan koperasi sekolah yang dimulai dengan kegiatan rapat pembentukan koperasi sekolah per kelompok dibuktikan dengan pengumpulan AD/ART koperasi masing-masing kelompok. Selanjutnya peserta didik melakukan kegiatan praktek koperasi diluar ruangan. Peran pendidik hanya sebatas mengarahkan, membimbing dan menjawab semua pertanyaan terkait masalah yang belum dikuasai. Tidak kalah penting pendidik mengamati semua kegiatan peserta didik lalu mencatatnya dalam buku nilai pengamatan sikap. Diakhir kegiatan dilakukan ujian tertulis untuk mengetahui tingkat pemahaman peserta didik terhadap materi yang diterima. 


\section{HASIL DAN PEMBAHASAN}

\section{Hasil}

1. Hasil pengamatan sikap peserta didik terlihat dalam tabel rekapitulasi pengamatan sikap per kelas dibawah ini:

Tabel 1. Rekapitulasi Pengamatan Sikap per Kelas

\begin{tabular}{|l|l|l|l|l|l|l|l|l|}
\hline \multirow{2}{*}{ No } & \multirow{2}{*}{ Kelas } & $\begin{array}{l}\text { Jumlah } \\
\text { Siswa }\end{array}$ & $\begin{array}{l}\text { Kerja } \\
\text { sama }\end{array}$ & Kreatifitas & Disiplin & Antusias & Keaktifan & Ket \\
\hline 1 & 12 IPS 1 & 29 & 85 & 90 & 90 & 90 & 90 & T \\
\hline 2 & 12 IPS 2 & 30 & 90 & 90 & 95 & 95 & 90 & ST \\
\hline
\end{tabular}

Keterangan rentang nilai:

1. Nilai $10-30=$ Sangat Rendah (SR)

2. Nilai $31-50=$ Rendah $(\mathrm{R})$

3. Nilai $51-70=$ Sedang $(\mathrm{S})$

4. Nilai $71-90=$ Tinggi $(\mathrm{T})$

5. Nilai $91-100=$ Sangat Tinggi $($ ST)

Dimulai dengan kegiatan pembentukan koperasi, menyusun perangkat koperasi, lalu memasarkan produk hasil kreasi peserta didik dan diakhiri dengan menghitung sisa hasil usaha. Dari tabel diatas terlihat nilai kerjasama, kratifitas, disiplin, antusias, dan keaktifan semua bernilai di atas 85 yang tergolong katagori tinggi.

Tabel 2.Rekapitulasi Nilai Ujian per Kelas

\begin{tabular}{|l|l|l|l|l|l|}
\hline No & Kelas & Jumlah Siswa & Ketuntasan Klasikal & Nilai Rata-rata Kelas & Ket \\
\hline 1 & 12 IPS 1 & 29 & $85 \%$ & 85 & T \\
\hline 2 & 12 IPS 2 & 30 & $90 \%$ & 88 & T \\
\hline
\end{tabular}

Hasil ujian tertulis juga menunjukan peserta didik dengan menggunakan metode eksperimental jumlah ketuntasan belajar kelas 12 IPS 1 dan 2 sebesar 85 dan 90 persen dan nilai ujian rata-rata sebesar 85 dan 88 .

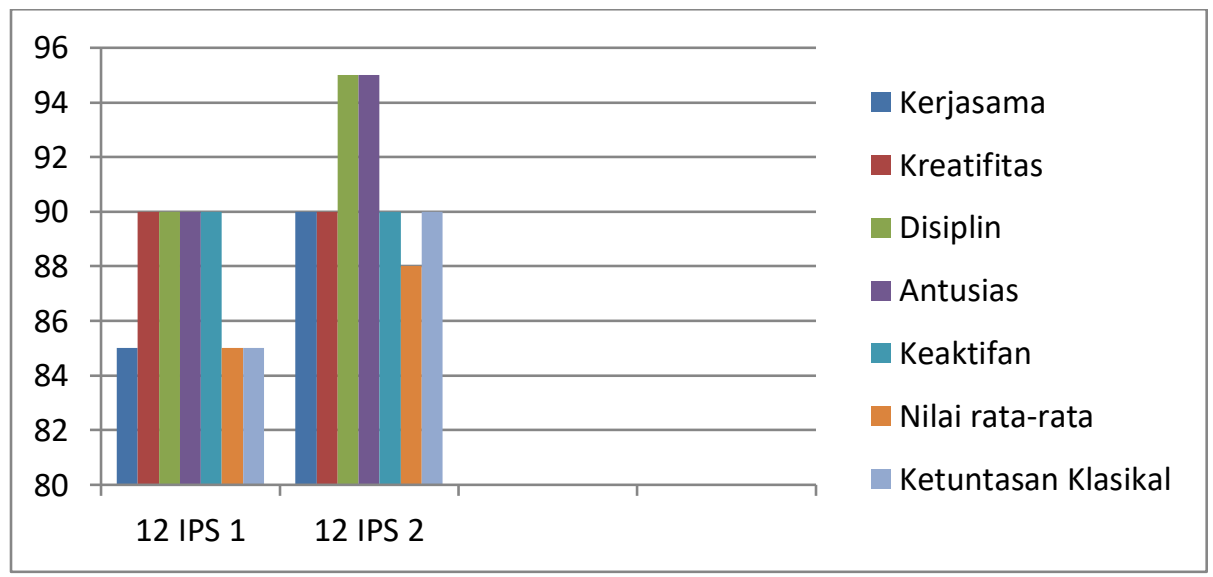

Gambar 1. Grafik Hasil Pengamatan Sikap dan Nilai Ujian 


\section{Pembahasan}

Dari nilai hasil pengamatan terlihat tingginya antusias, disiplin, keaktifan, dan kerjasama peserta didik dalam mengikuti setiap urutan kegiatan yang bernilai diatas 85, hal ini terjadi karena kegiatan lebih menitik beratkan kegiatan kepada peserta didik. Kegiatan juga dilakukan sebagian besar diluar ruangan membuat peserta didik tidak jenuh bahkan gembira dalam beraktifitas berdagang. Serta kegiatan pembelajaran yang dilakukan secara praktek langsung lebih meningkatkan antusias, keaktifan serta kerjasama peserta didik dalam belajar karena tidak banyak menggunakan teori (teks book). Kegiatan berdagang ini juga menumbuhkan kreatifitas peserta didik dalam melakukan transaksi dalam mendapatkan keuntungan, salah satunya dengan memanfaatkan kecanggihan teknologi contohnya melakukan pemasaran melalui sosial media ( WA, facebook ). Terbukti juga peserta didik yang lebih kreatif dalam memilih produk serta pemasarannya memiliki jumlah sisa hasil usaha yang lebih tinggi dibanding peserta didik yang kurang kreatif.

Dari data hasil nilai ujian terlihat bahwa tingkat ketuntasan peserta didik diatas 85 serta nilai ketuntasan klasikal kelas berhasil mencapai ketuntasan klasikal (>85\%). Keberhasilan ini lebih baik dari pada tahun-tahun sebelumnya dengan menggunakan metode pembelajaran lain, dengan hasil yang sulit mencapai ketuntasan kalsikal. Satu kelas dikatakan tuntas belajarnya apabila $>85 \%$ dari seluruh jumlah siswa telah mencapai KKM (Trianto,2009).

Hasil ini sejalan dengan hasil penelitian tentang pengunaaan metode eksperimental yang dilakukan oleh Rahmawati, Maldona \& Gaffar(2018), bahwa ada pengaruh metode belajar eksperimen terhadap hasil belajar siswa pada konsep Energi dalam sistem kehidupan di Kelas VII SMP N 1 Ciamis. Serta Penelitain Sari \& Muhartono (2018), pengalaman belajar blok Emergency mahasiswa kedokteran UNILA didapatkan bahwa 49,7\% mempunyai pengalaman belajar yang baik, 32,4\% cukup,13,4\% kurang dan 4,5\% sangat baik.

\section{KESIMPULAN}

Hasil data yang diperoleh dari penilaian pengamatan sikap terlihat tingginya antusias, keaktifan, disiplin serta kreatifitas peserta didik pada mteri koperasi sekolah. Materi yang selama ini aplikasinya sulit difahami peserta didik dengan metode yang biasa dilakukan dapat dicapai dengan penerapan metode ekpserimental. Dengan penggunakan metode ini terlihat antusias peserta didik dalam melakukan praktek langsung koperasi sekolah, di mulai dari pembentukan koperasi, pelaksanaan berdagang serta penghitungan sisa hasil usaha. Hasil ujian tertulis juga tercapainya ketuntasan klasikal dengan nilai rata-rata yang cukup tinggi dibanding tahun-tahun sebelumnya.

Dengan demikian penerapan metode pembelajaran eksperimental yang dilakukan di SMAN 1 seputih Raman Kab. Lampung Tengah tepatnya pada materi koperasi sekolah memiliki dampak positif terhadap pengalaman belajar peserta didik. Harapan kedepan, pengalaman praktek langsung koperasi tersebut dapat bermanfaat bagi peserta didik bila kelak mereka hidup dimasyarakat dan dipercaya mengelola koperasi.

\section{DAFTAR PUSTAKA}

Apandi. Indris. (2018). Kiat Praktis menulis Best Practice bagi Pendidk dan Tenaga Kependidikan. Ciamis: Tsaqiva Publishing.

Brolin, D.E. (1989). Life Carrer Education: A competency.Based Approach Reston VA; The Council for Exeptional Children.

Daryanto. (2009). Panduan Proses Pembelajaran Kreatif \& Inovatif. Jakarta: AV Publiser.

Dawson. Kara dan Ann Kovalchick.ed,.(2004). Education and technology: an encyclopedia. California: ABC- CLIO, Inc.

Djamarah Syaiful Bahri. (2002). Strategi Belajar Mengajar. Jakarta : Rineka Cipta

Rahmawati. Dina, Maldona. Adi \& Gaffar, Aden.Arif (2018). Pengaruh Metode Pembelajaran Eksperimen Terhadap Peningkatan Hasil Belajar Siswa (Studi Eksperimen di Kelas 
VII SMP pada Konsep Energi dalam Sistem Kehidupan). Jurnal Bio Educatio, Vol. 3, No. 2, hlm.08-13.

Roymond. H.Simamora. (2009). Buku Ajar Pendidikan Dalam Keperawatan. Jakarta : EGC. Sari.Anggita.Gardeesna \& Muhartono. (2018). Pengalaman Belajar Mahasiswa Fakultas Kedokteran Universitas Lampung. Jurnal majority, Vol.7, No.3. hlm. 138.

Suryosubroto, B. (2002). Prose Belajar Mengajar Di Sekolah. Jakarta: Rineka Cipta.

Trianto. (2009). Mendesain Model Pembelajaran Inovatif Progresif. Surabaya: Kencana. 